\title{
Exploration of Postcolonial Subaltern World in the Literary Works of Maya Angelou and Mukhtar Mai
}

\author{
Jitendar ${ }^{1}$ \\ ${ }^{1}$ Research Scholar, Department of English, Himachal Pradesh University Shimla, India. \\ E-mail kashavjitendar@gmail.com | ORCID ID:
}

Prof. Rekha Sharma ${ }^{2}$

2 Dean, Department of Languages Himachal Pradesh University, Summer Hill, Shimla, India.

E-Mail rekhahpu@gmail.com | ORCID ID: 000-0003-4964-7748

\begin{abstract}
Literature is substantially influenced by ancient and modern theories of literary discourse from the age of Plato and Aristotle, all such theories have played an important role to challenge the set conventions and rules of literature; a major transition is underway in literary discourse. After the emergence of modern and postmodern literary theory, the themes and trends of literary studies have challenged by number of emerging theories. The result of this changing trend in is in the form of romanticism, feminism, impressionism, imagism, existentialism, structuralism, modernism, postmodernism, and even post-structuralism. To challenge the historiography of postcolonia] studies there emerged another branch of study known as subaltern studies. The writers have exposed oppression at the societal, religious and gender levels. It is found that there is an intense period of disillusionment in the history of marginalized women and their representation in the form of writings. They register their protest and resist whatever is detrimental to their quest of identity and self-worth. Literary exploration of self and other is an attempt to give voice to the unvoiced, on the untrodden paths, to investigate the uninvestigated. It is an enterprise to retrieve the void, and the silences in the text mediated, twice through trans-literation and transition. In this research paper an attempt has been made to understand the conditions of women in Africar American and Pakistani Tribal societies. The two life writings, one of Maya Angelou I Know Why the Cage Bird Sings and the other In the Name Honor by Mukhtar Mai are used to examine their situations in their respective societies under Subaltern perspective.
\end{abstract}

Keywords: Subaltern world, Postmodernism, Postcolonial, Disillusionment, Caged bird

\section{Introduction}

The women literary tradition is increasingly concerned about the consciousness of women and the canon of subaltern literature is providing a space for oppressed classes of the society. The fictional world is now allowing women writers to stand on their own, than be in the shadow of man. 
The major impact of contemporary literary theories such as New Criticism, Post-Structuralism, Postmodernism and Subaltern Studies has been the construction and deconstruction of all conventional thoughts and epistemological binaries. The oppression of women is prevalent across the world through the overarching system of patriarchy, but its implications and manifestations are different in subaltern countries and in the third world countries. The colonized countries are now free from colonial rule; still they are mentally trapped in the subtle forms of domination under neocolonialism. To challenge the historiography of postcolonial studies there emerged another branch of study known as subaltern studies.

In the last thirteen years the subaltern studies groups has produced a fairly large amount of literature and its impact has been felt beyond India. Over the years numerous critiques were made of subaltern studies within India, as well as in Britain, Latin America and the United States (Ludden 358).

The world which the subaltern women inhabit allows one to know her and her experiences in the different faces of life, as she confronts aggression and subjugation and learns to confront it. The recent development of women writings have increasingly brought specifically female themes into their writings such as subjugation, oppression, sexism, racism sexual exploitation, loneliness, uprooting leading to anguish and a sense of displacement. All such themes are becoming the main concern of contemporary women writers.

Subaltern literature nowadays forms a significant part of contemporary literary tradition. In the words of Julian Wolfrey, "It contains the groups and Individuals that are marginalized, oppressed and exploited on the cultural, gender, socio-political, and religious grounds." (Satyanarayana 8) As subjugation of colonial people is highlighted by subaltern theorists, same themes have been penned down by Maya Angelou and Mukhtar Mai. The literature of Africa and Pakistan was mainly dominated by men, but writers like Maya Angelou and Mukhtar Mai are breaking these stereotypes of literary creation.

The two autobiographical works by Mukhtar Mai and Maya Angelou portray their struggle to survive in a world where male dominance and racial discrimination force women to live a life which is beyond any special right or privilege. In Mukhtar Mai's case politically powerful group of tribal Mastoi caste force her to be gang raped in the name of family honor, and as far Maya Angelou is concerned she faces racial and sexual oppression in her society; this portrayal of subjugation is portrayed by her in I Know Why the Caged Bird Sings.

In the Name of Honor and I Know Why the Caged Bird Sings are powerful expressions of women emancipation by raising their consciousness. They strongly display their rejections of prejudices and patriarchal laws in tribal society of Pakistan and racial African American society. Mukhtar Mai in her memoir perceives the socio-political and judicial reality in Pakistan in proper perspective, and revolts to claim her rights. In most of the cases of gang rape and brutality of sexual exploitation women commit suicide but Mukhtar Mai decides to fight for justice: 
I have made up my mind: I want to kill myself ... that is what women in my situation do. I will swallow acid and die, to put out for ever the fire of shame that torments my family and me. I beg my mother to help me die she must go buy some acid, so that my life may finally end, since I am already dead in the eyes of others! My mother bursts into tears, and by staying at my side day and night, she foils my suicide attempt. I can't sleep, and she won't let me die, for several days I go insane with helplessness. I cannot go living like this, lying down, shrouded in my shadow finally but of nowhere, a surprisingly fit of anger saves me from that stupor (Mai 13).

In such situations under which women like Mukhtar Mai are likely to surrender to their convention of submissive and passive roles she gains strength and courage. 'Hudood' and other customary laws are such cultural practices which are designed to control and subjugate women in Pakistan. Under 'Jirga' law Mukhtar Mai was punished to be gang raped in the name of family honor. This heartbreaking portrayal of her rape case forces her to put forward her voice against women oppression across the world.

Women Rights Organization and Human Rights Organizations have played an important part in providing justice to Mukhtar Mai by protest, debates, and discussions on numerous platforms. Mukhtar Mai's rape has highlighted one of the biggest problems that Pakistan is facing in the judicial system. The role of tribal councils and their abuse of power to protect particular social group is the main concern in the autobiography of Mukhtar Mai and which highlights importance of Subaltern study under which we can explore the themes of oppression on different levels of life. Mukhtar Mai has provided a platform to Pakistani women to challenge these customary laws.

Women must write herself, must write about women and bring women to writing, from which they have been driven away as violently as from their bodies, for the same reasons, by the same law, with the same fatal goal. Woman must put herself into the text - as into the world by her own movement. (Cixous 75).

The abusive nature of tribal council becomes widely known after her case. Women Organizations and Human Rights Organizations in Pakistan started protesting against it; 'Zina-bil-Jabar' (Under Sharia, forcible sexual relations) is forbidden under Shariyat Law but to prove 'Zina-bil-Jabar' a woman needs to provide four eyewitnesses under 'Hudood.'Being an illiterate woman it becomes tougher for Muktar Mai to receive justice under such justice system of tribal councils

Like many illiterate women, I knew nothing about the law, and so little about my rights that I didn't even know I had any! Now, though I'm beginning to understand that my revenge can take another path besides suicide. What do I care about threats or danger? What could be worse than what I just went through! My father, to my surprise, supports my decisions to fight back (Mai 27). 
With all odds-on different levels of journey, Mukhtar Mai remains firm on her revenge. Patriarchal family system does not allow women to raise their voice and give their opinion regarding any issue; this subjugating nature forces Mukhtar Mai to go and face 'Jirga' council but under 'Jirga' law she was convicted to be gang raped by Mastoi people. This decision forces her to challenge the decision of 'Jirga' council gave her strength to challenge these inhuman laws in higher places of justice.

I may be poor and illiterate and perhaps I've never struck my nose into man's business, but I have ears to hear and eyes to see. Plus a voice to speak, and to speak up for myself (Mai 30).

Women portrayed by Maya Angelou and Mukhtar Mai have challenged their respective sociocultural systems. Their portrayal of struggle shows that they do not submit passively to the conditions and situations imposed on them. Both writers resist patriarchal and racial attitudes in their respective texts. In I Know Why the Caged Bird Sings Maya Angelou challenges the norms and values fixed for African Americans in Stamps. The racial tools are adopted by African Americans to subjugate women by invoking ancient cultural submissive norms for women. "Maya Angelou's $I$ Know Why the Caged Bird Sings is an autobiographical narrative about the writer's gradual awareness of her body. The story of her individual life is extended to the community by its explicit reference to and involvement of the African-American society" (Paul 65).

Both the texts are sagas of oppression, resistance and subjugation of women. The racial discrimination against blacks is common in American societies. It is not only an extremely humiliating practice but also strips the African Americans of the dignity and self-respect. After facing all these atrocities black people remain loyal towards their country and their nation.

Stories of law violations are weighed on a different set of scales in the black mind and then in the white. Petty crimes embarrasses the community and many people wistfully wonder why negroes don't rob more banks, embezzle more funds, and employ graft of the unions ... life demands a balance it is all right if we do a little robbing now: this belief appeals particularly to one who is unable to compete legally with his fellow citizens (Angelou 240).

The women in African American society, especially black, always remain passive, for any sort of resistance to racial prejudices was punished by white masters. The women who refuse to obey white masters were thrashed and humiliated even by white females. Maya Angelou's autobiography, I Know Why the Caged Bird Sings, is full of such experiences in African American society. Black peoples' loyalty for the white masters and their struggles for survival in society evoke a sense of concern among readers. In this text, Maya Angelou casts off racial stereotypical roles and projects them in a new light. She emphasizes through that, "Black women should heal themselves by loving their bodies and communities, while white women should learn to love their black counterparts as a means of definitively eradicating the epidemic of racism." (Nunez-Puente)Her texts are shining examples of black woman's resourcefulness, courage, and determination in the face of sexual exploitation and oppression. 
Violence is the frequently adopted mode of suppressing women both inside and outside home; it can be sexual, economic, political and cultural oppression. It is not only restricted to physical abuse in the form of rape, beating and female genital mutilation, but extends to the whole person of woman in the form of emotional and mental trauma. Subaltern studies task is to study the consciousness of individuals who faced this type of subjugation. "To reveal the subjectivity of the rebel is the central concept in subaltern world." (Chowdhury) All these forms are presented by Maya Angelou and Mukhtar Mai in their autobiographies. The themes of suppression and subjugation dominate both texts; woman is treated merely as a creature of flesh available to satisfy the needs of men- physical, sexual, domestic, and even economic. The tribal societies in Pakistan and black societies in Africa and America have these prejudices. Now the women from these societies are ready to break the shackles of patriarchal codes to assert their selves:

The black female is assaulted in her tender years by all those common forces of nature, at the same time that she is caught in the tripartite crossfire of masculine prejudice white illogical hate and black lack of power (Angelou 291).

Maya Angelou is one such African-American woman who is likely to be sacrificed in the name of patriarchal tradition but she asserts her individuality instead of submitting to traditional mores. She becomes a new African woman, who has the courage and will to rebel against the accepted traditional customs and practices.

The inhuman cultural practices in Muslim tribal societies are considered by Mukhtar Mai. These customary laws and their side effects upon common masses of Pakistan is the issue of concern around the world. One such inhuman practice of female genital cutting is still prevalent in Muslim societies.

Female genital cutting is a procedure that is performed on the genital tissue of a female ranging in age from infancy to adulthood. The practice is viewed by some as a traditional rite of passage and by others as an unnecessary painful and harmful procedure that can leave a female with physical and psychological imbalance and can even result in death (Encyclopedia Britannica 1).

The inhuman and submissive attitude towards women has been challenged in Pakistan and other Muslim societies after the gang rape of Mukhtar Mai. It got the spotlight of world media and human rights organizations. Mukhtar Mai and Maya Angelou are two revolutionary women in their respective societies who challenge the cultural and political oppression. They write their stories because they want the world to know that the practice of female racial-sexual oppression is a gross violation of human body, physically as well as psychologically. As a result, especially in case of Mukhtar Mai, the publicity which she got, various human rights organizations and Pakistan government invest more money towards the education of the girls in tribal regions of Pakistan. She has also established a school in her village for the girls from the money which she received as compensation from governmental authority: 
Aside from the need to educate girls, to give girls the chance to reach the outside world through literacy, most important thing I've discovered is self-knowledge: the knowledge of oneself as a human being. I have learned to exist and to respect myself as a woman (Mai 112).

Maya Angelou and Mukhtar Mai are living examples of the courage and endurance for the women of the world. Their autobiographies, In the Name of Honor and I Know Why the Caged Bird Sings, represent the true spirit of the subaltern women. Their rebelling spirit becomes a guiding spirit for all the women who become victims of oppression and discrimination. The autobiographies discussed is an exercise in conscious raising as they provide a platform to voice the concerns of the oppressed that call forth for a better world to live in.

The select works foreground the life conditions of women across the spectrum of class, status, religion, ethnicity, and nationality. These real-life stories pertain to women's liberation from a host of personal and socio-cultural shackles. Every reader has been struck by the truthful picture of self recognition present therein. In these stories, Maya Angelou and Mukhtar Mai narrate their life stories, dealing with their parents, husbands and innumerable social norms and patriarchal notions. Their stories are the realistic depiction of human relationships foregrounding their lives and the world enmeshed in circumstances which were oppressive and unjust to the hilt. The protagonists have been brought together by an unbelievable change in their lives and courage shown against the formidable circumstances. In one of her poem Phenomenal Women Maya Angelou talks about the beauty and self-perception of women which should be respected and appraised in every society she writes

\author{
"It's in the fire in my eyes \\ And the flash of my teeth, \\ The swing in my waist \\ And the joy in my feet \\ I'm a woman \\ Phenomenally Phenomenal woman, \\ That's me" (․ㅡgelou 65).
}

Another noteworthy feature of these protagonists is how and why they change. They are not what they were at the beginning of their narratives. Each of them develops from an innocent, weak and docile woman to strong, optimistic, and self-assertive personality. Although they adhere to the societal norms and the demands of relationships in many ways, however, at the end, they become openly defiant and rebellious to the extent of totally rejecting the norms of patriarchy. They build up an identity and individuality of their own since they are no longer willing to accept their subservient positions of compromise and conformity. They know very well that this decision of theirs will make them walk extremely arduous paths. But once these protagonists decide to defy the decadent customs and traditions of the patriarchal society, they remain entirely fearless. 
Ranajit Guha in his book on subaltern studies emphasizes that, "A new vista of Inquiry was opened up to understand the sufferings and pain of marginalized women in postcolonial countries by Subaltern studies and

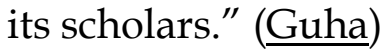

Another aspect that comes up on reading these texts through the prism of Subaltern theory is the similarities in the real position of women irrespective of caste, class, religion, ethnicity, and educational background. The atmosphere in which these women lived was invariably oppressive, violent and extremely unjust. As a result, they take on all sorts of odds in their struggles for selfdiscovery and self-respect. Regardless of their differences, these women come across as authentic human beings. Through their struggles, they have set an example for hundreds and thousands of women living in third and fourth world countries as subjugated subaltern objects that they can do anything if they want to liberate themselves of the shackles of patriarchy and oppression. Finally, they succeed in exposing the shallowness and hypocrisies of the male dominated world.

\section{Conclusion}

Indeed, writing is a highly effective way to express oneself; Angelou and Mai seek solace from the injuries and anguish of their past by engaging themselves in writing. It may not be wrong to say that these real-life heroines break out of the societal cages. They learn slowly from their daily experiences that they are equal to men in every way that they must strive for equality in all spheres - domestic, professional, societal, legal and religious. The awakening, assertion of their selves lead them to the path of self-realization which further boosts their morale and strengthens their will to put up a fight against oppression and all kinds of discriminations. All these associative characteristics of women writings were stressed by subaltern theorist to provide a better space to subjugated souls around the world.

The writings of these women show their amazing struggles against all odds and horrendous circumstances. Undoubtedly, they come forth as strong women who speak out confidently against the sanctioned abuse of women. Through their journeys, they win victories over the masculine world and establish a deserving place for themselves. Their life writings-cum-memoirs are not merely books, rather they are their lived, felt, perceived experiences which give them the courage to take on the might of the whole exploitative world and carve out a place for themselves courageously and effectively. Thus, they succeed, to a great extent, in reinventing their selves and conveying to their sisters around the world to look for and nourish the seeds of self-awareness and self-concretization that alone can lead them to say no to oppression and aspire for freedom of thought, word and deed. 


\section{References}

Angelou, Maya. Phenomenal Woman. NewYork: Random House Publishing, 1994.

Angelou, Maya. I Know Why The Caged Bird Sings. New York: Random House, 1969. Print.

Maya Angelou (1977) Interviews: Maya Angelou, The Black Scholar, 8:4, 44-

53, DOI: $10.1080 / 00064246.1977 .11413883$

Cixous, Helene. "The Laugh of Madusa." Women And Values: Reading In Recent Feminist Philosophy. Ed. Marilyn Pearsall. California: Wadworth (1999). Print.

Chowdhury, Arnab Roy. "Subaltern Studies." Sangeeta Ray, Henry Schwarz, José Luis Villacañas Berlanga, Alberto Moreiras and April Shemak. Encyclopedia of Postcolonial Studies. U.S.A: Wiley and Blackwell, 2016. 26. Print.

"Female Genital Cutting: Why it is Prevalent in Some Societies and Why it is Opposed in Others." Encyclopedia. 9, Sep (2016).

Guha, Ranajit, and Gayatri Chakravorty Spivak. 1988. Selected Subaltern Studies. New York: Oxford University Press.

Ludden, David. "Reading Subaltern Studies: Critical History, Contested Meaning and the Globalization of South Asia." EPW 8 (2003). Print.

Mai, Mukhtar. IN THE NAME OF HONOR: A MEMOIR. Trans. Linda Coverdale. Great Britain: Virgo, 2007. Print.Roy Choudhury, Arnab.

Nunez-Puente, Carolina. "Women's Poetry that Heals across Borders: A Trans-american Reading of the Body,Sexuality, and Love." Feminismo/s (2021): 337. Print.

Satyanarayana, Dr. P. "Subaltern Studies." International journal of Research Granthalayah: A knowledge Repository (2016): 8-12. Print.

"Subaltern Studies." The Encyclopedia of Postcolonial Studies. Ray, Sangeeta, Henry Schwarz, José Luis Villacañas Berlanga, Alberto Moreiras and April Shemak (eds). Blackwell Publishing, 2016.

Spivak, Gayatri C. 1988. Subaltern Studies: Deconstructing Historiography. In Selected Subaltern Studies, eds. Ranajit Guha and Gayatri C. Spivak, 3-32. New York: Oxford University Press. Print.

Author Bio:

Jitendar is a PhD Research Scholar in the Department of English, Himachal Pradesh University, Summer Hill Shimla.

Prof. Rekha Sharma, Professor and Dean, Faculty of Languages, Himachal Pradesh University, Summer Hill Shimla. 